\title{
Major Role for CD8+T Cells in the Protection Against Toxoplasma gondii Following Dendritic Cell Vaccination
}

\author{
Isabelle Dimier-Poisson \\ UMR ISP 1282 University-INRA, \\ Parasite Immunology, Vaccinology and Anti-Infectious Biotherapies, \\ University François Rabelais, Faculty of Pharmacy, Tours,
}

France

\section{Introduction}

Toxoplasma gondii is an obligate intracellular protozoan that infects one-third of the world population. Asymptomatic in immunocompetent hosts, toxoplasmosis has severe consequences in immunosuppressed individuals and can even lead to death. ${ }^{1,2}$ Congenital toxoplasmosis causes development of sequelae later in life, including chorioretinitis, hearing loss or mental retardation. ${ }^{3}$ Toxoplasma gondii is also recognized as being a major cause of abortion in farm animals, such as sheep and goats thus causing substantial reproductive and economic losses. ${ }^{4}$ Additionally, these infected animals are a parasitic reservoir involved in human contamination. Recently it has been reported that Toxoplasma gondii has some degree of causal relation to Schizophrenia ${ }^{5}$ because of the positive relationships between the prevalence of Toxoplasma antibodies and the development of schizophrenia. A recent article reports that Toxoplasma infection in rodents blocks the aversion toward predator odors and develop an attraction suggesting an integrating effect of the parasite. ${ }^{6}$ This study provides an example of the behavioral effects of Toxoplasma in models of psychiatric and emotional conditions.

Once human beings or animals have been infected, no drug treatment available at present will eliminate the parasite. Nor is there any vaccine for human use to control the disease.

Primary infection with T. gondii results in the setting of both humoral and cell-mediated immune responses and confers long-term protection. This suggests that the development of an efficient vaccine is a realistic goal. Moreover because of the enormous estimated costs and social impact of $T$. gondii infection and the fact that primary infection with this parasite could give the host a protective immunity against re-infection, many studies have investigated possible solutions for an efficient vaccine. ${ }^{7,8}$ However the immune response set following a $T$. gondii infection firstly needs to be clearly defined before a vaccine can be developed.

Host resistance seems to occur via synthesis of IFN- $\gamma$ by NK cells and adaptive T lymphocytes. ${ }^{9}$ Following infection, antigen-presenting cells synthesize TNF- $\alpha$ and IL-12 
which induce NK cells to secrete IFN- $\gamma$. The combined action of IL-12 and IFN- $\gamma$ induce a strong differentiation of T helper precursors into Th1 lymphocytes. These CD4+ T cells then synthesize large amounts of IFN- $\gamma$ and IL-2. These two cytokines finally induce CD8+ T lymphocytes proliferation and IFN- $\gamma$ secretion. ${ }^{10}$ Thus protection against $T$. gondii infection is mainly attributed to cell-mediated immunity.

Previous studies have shown that both CD4+ and CD8+ T-cell subtypes are involved in the protection and the relative contribution of these two populations was investigated by adoptive transfer or in vivo depletion. ${ }^{10}$ The transfer of $\mathrm{T}$ cells from infected or immunized mice to naïve mice provided protection against a lethal challenge of $T$. gondii, but this protection was abolished by depletion of CD8+ T cells prior to transfer but not by depletion of CD4+ T cells 11,12 . Similarly, transfer of $\mathrm{CD}^{+} \mathrm{T}$ cells from chronically infected mice to naïve WT or nude mice was also able to provide protection from $T$. gondii challenge ${ }^{11}$. However, in response to T. gondii, the lack of $\mathrm{CD} 8^{+} \mathrm{T}$ cells could be compensate by a potent NK cell response, though $\beta 2$-m-deficient mice remained more susceptible than WT mice.13 All these data suggest a prominent role of CD8+ cells with a supporting role for CD4+ cells during the acute phase as well as during the chronic phase of infection.

$\mathrm{CD}^{+} \mathrm{T}$ lymphocytes mediated protection by IFN- $\gamma$ which has been demonstrated to be crucial by studies using neutralizing antibody to IFN- $\gamma$ or mice deficient in its production 14 , 15, 16. Evidence that production of this cytokine and subsequent protection against toxoplasmosis is dependent on $\mathrm{CD}^{+} \mathrm{T}$ cells was demonstrated by showing that treatment of infected mice with anti-CD8 antibodies resulted in reduced production of IFN- $\gamma$ and loss of IFN- $\gamma$-mediated protection. $17,18 \mathrm{CD}^{+} \mathrm{T}$ cells can also mediate perforin-dependent cytotoxicity against target cells that present the correct peptide in the context of MHC on their cell surface. Several studies have shown that CD8 ${ }^{+} \mathrm{T}$ cells isolated from immunized or infected mice lysed infected cells or targets pulsed with Toxoplasma antigens19,20, 21,22. All these data suggest a prominent role of CD8+ cells during the acute phase as well as during the chronic phase of infection.

If IFN- $\gamma$ is the major cytokine of resistance to T. gondii, IL-12 is a crucial initiation cytokine to trigger an efficient cell-mediated immunity. Indeed, IL-12 is a major cytokine secreted in response to $T$. gondii by neutrophils ${ }^{23}$, macrophages ${ }^{24}$, plasmacytoid dendritic cells (pDCs) ${ }^{25}$, conventional dendritic cells (cDCs) ${ }^{26}$ and the subset of cDCs expressing CD8 $\alpha^{27}$. Recently Mashayekhi et al have demonstrated the critical role of CD8 $\alpha+$ DCs for activation of innate immunity through IL-12 production during T. gondii infection and have shown that CD $8 \alpha+$ DCs are the only cells whose IL-12 production is required to control acute infection ${ }^{28}$.

IL-12 is produced in response to Toll-like receptor (TLR) recognition of molecular structures broadly conserved across microbial species ${ }^{29}$ that triggers the early IFN- $\gamma$ secretion following T. gondii infection. IFN- $\gamma$ activates various cell-intrinsic antiparasitic defense defense pathway within infected cells for intracellular elimination of Toxoplasma, including the activation of interferon-regulated GTPases (IRGs) ${ }^{30,31}$, induction of reactive nitrogen intermediates ${ }^{32}$, tryptophan degradation in human cells ${ }^{33}$, and autophagy ${ }^{34,35}$.

So DCs are the first producers of IL-12 in response to T. gondii antigens and several previous studies suggest that DCs play an important role in the setting of the immune response to the intracellular parasite T. gondii during the early and chronic phases of infection. 
The central role of DCs in controlling immunity makes these cells ideal tools for priming functional immune responses. Many studies have proposed the use of DCs as vaccine vectors. For instance, T. gondii extract-pulsed splenic DCs administered in vivo induce a strong humoral and cellular immune response and promote protection against a virulent challenge. ${ }^{36,} 37$ It has been also observed that Toxoplasma pulsed DCs induced protective immunity against $T$. gondii infection in both syngeneic and allogeneic mouse models. This protection was associated with the induction of humoral and cellular Toxoplasma-specific responses ${ }^{38}$. However, expensive treatments of this type, based on living cells, could be envisaged only for severe diseases, such as cancers, which are specific to the individual due to MHC restriction. For ethical reasons, it is not possible to use live cell lines in an immunisation protocol in humans. New approaches, involving the development of non-live and DNA-free vaccines, must therefore be pursued. Moreover, the use of DCs is limited by the difficulty of obtaining large numbers of cells suitable for vaccination purposes.

If DCs can effectively process $T$. gondii antigens for presentation in vivo, their use in a vaccine strategy is not acceptable. It is of interest to study the effector mechanisms induced by $T$. gondii-sensitized dendritic cells as a well-described protective immune response would help the development of new efficient vaccine strategies.

So the relative contribution of two main lymphocytic populations, CD4+ and CD8+, was investigated in a model of chronically infected mice, following dendritic cell vaccination and lymphocyte depletion.

We first determined the role of CD4+ T lymphocytes after an efficient depletion of over $90 \%$. The results revealed a minor role for these cells since CD4-depleted or non depleted mice have similar cytokine secretion profiles in spleen as well as in MLNs. Moreover, depleted mice did not show any significant loss of protection in terms of brain cyst load. These results contrast with those obtained by Casciotti in 2002. ${ }^{10}$ They demonstrated that CD4+ T cells are important for early IFN- $\gamma$ production during T. gondii infection and that lack of CD4+ lymphocytes leads to parasite multiplication in the tissues. Moreover CD4 deficient mice exhibited parasite burdens in the brain. Johnson and Sayles also showed the implication of CD4+ cells as they induce CD8+ T cells through the production of IL-2 and maintain CD8+ T cells effector immunity. ${ }^{39} \mathrm{CD} 4+\mathrm{T}$ lymphocytes also contributed significantly to protection against chronic infection via their role as helper cells for production of isotype-switched antibodies. The contradictory results obtained following infection alone or following vaccination plus infection could result from a particular orientation of the immune response. Indeed, in our protocol dendritic cells could directly prime CD8+ T lymphocytes via crosspresentation of T. gondii antigens, as previously demonstrated by Gubbels et al. 40

So CD4+ T lymphocytes appeared to be not implicated either in spleen or mesenteric lymph node cytokine secretion or in long-term protection of mice.

We next studied the implication of CD8+ T lymphocytes after an efficient depletion of over $90 \%$. In spleens CD8+ cells seem to be responsible for cytokine synthesis. Indeed, their depletion leads to a significant decrease of both Th1 (IFN- $\gamma$ and IL-2) and Th2 (IL-10 and IL4) cytokines. We further confirmed these data by identifying the CD8+ T cells as the IFN- $\gamma$ producing cells. These results are in accordance with another vaccination assay where Gazzinelli et al. got similar results. They vaccinated BALB/c mice with the mutant $T$. gondii strain TS-4 before depleting them of CD4+ or CD8+ lymphocytes and challenging them with 
a lethal dose of tachyzoites. They identified IFN- $\gamma$-producing CD8+ T cells as the major effectors of immunity in vivo. ${ }^{41}$ Moreover, in our experiment, CD8+ cells depletion induced a loss of protection in mice previously immunized with pulsed dendritic cells, so CD8+ cells are crucial for CBA/J mice resistance to $T$. gondii infection. CD8+ cells also appear to play a major role in Trypanosoma cruzi infection. Mice lacking CD8+ T-cell function fail to control a normally non-lethal infection and die early in the acute phase. Moreover, depletion of CD8+ T cells in the chronic phase results in increased parasite load. ${ }^{42}$

In contrast to spleens, MLNs showed increased secretions of cytokines following CD8+ depletion suggesting that CD8+ T lymphocytes could act as regulatory cells. A recent review summarizes the current knowledge on CD8+ Tregs, a newly described CD8+ lymphocyte subtype with dedicated suppressor function. ${ }^{33}$ Although not proven in parasitic infections, their importance in autoimmunity is well-documented and they could be responsible for the moderation of the immune response set in local lymph nodes. It would be of importance to determine which cell population is responsible for the MLN IFN- $\gamma$ secretion. It has been demonstrated that splenic NK cells could produce this cytokine in response to T. gondii in MHC-I deficient mice thus unable to activate CD8+ T cells. ${ }^{44}$

So CD8+ T lymphocytes appeared as the main effectors, inducing a strong Th1 response in spleen while inhibiting both Th1 and Th2 responses in mesenteric lymph nodes.

This is the first study to point to CD8+ lymphocytes as the unique effector population responsible for the protection of mice following efficient DC vaccination and subsequent virulent challenge. This is partly in accordance with a previous description of CD8+ T cells as effector lymphocytes while CD4+ T cells were crucial for the regulation of the immune response in a very different vaccination assay. ${ }^{17}$

We provide further insight into the long-term immunity that protects mice against T. gondii, a ubiquitous parasite resulting in severe sequelae in immunocompromised individuals. Future studies will be needed to determine how T. gondii antigens are presented to CD8+ lymphocytes. A recent study showed encouraging results. Indeed, the authors demonstrated that CD8+ DCs were very efficient in processing and cross-presenting exogenous antigen to CD8+ T cells. They also highlighted CD24 as an essential co-stimulatory molecule required for CD8+ DCs to generate CD8+ and CD4+ T-cell responses. ${ }^{45}$ The possible roles of various CD4+ lymphocyte subtypes and other immune cell populations during the chronic phase of the disease also need to be elucidated, with a view to developing an effective vaccine to be used in animals that serve as a natural reservoir for human contamination.

Finally, the next step to efficiently develop a vaccine strategy will be to identify which parasitic peptides are cross-presentated by DCs to CD8+ T cells to initiate the specific protective response to $T$. gondii. Blanchard et al. recently found that a decapeptide from the dense granule protein GRA6 could effectively induce such protection against $T$. gondii, as assessed by survival of mice. ${ }^{46}$ However, their study was conducted using bone marrowderived DCs. It could be of interest to target in vivo splenic CD8+ DCs, known to protect our mice, with such putative protective parasitic peptides.

Fully dissecting the cellular and molecular events leading to this protective response will allow for better design of vaccine strategies to enhance immunity and decrease morbidity and mortality associated with Toxoplasma infection. 
Thus, transfer of Toxoplasma antigens to lymphoid resident DCs is a feature of DC vaccination that can be exploited to improve vaccine outcome.

\section{References}

[1] Hoffmann C, Ernst M, Meyer P, Wolf E, Rosenkranz T, Plettenberg A. Evolving characteristics of toxoplasmosis in patients infected with human immunodeficiency virus-1: clinical course and Toxoplasma gondii-specific immune responses. Clin. Microbiol. Infect. 2007; 13: 510-15.

[2] Barsoum RS. Parasitic infections in organ transplantation. Exp. Clin. Transplant. 2004; 2: 258-67.

[3] Elsheikha HM. Congenital toxoplasmosis: priorities for further health promotion action. Public Health. 2008; 122: 335-53.

[4] Bennett R, Christiansen K, Clifton-Hadley R. Preliminary estimates of the direct costs associated with endemic diseases of livestock in Great Britain. Prev. Vet. Med. 1999; 39: 155-71.

[5] Yolken RH, Bachmann S, Rouslanova I, Lillehoj E, Ford G, Fuller Torrey E et al. Antibodies to Toxoplasma gondii in individuals with first-episode schizophrenia. Clin. Infect. Dis. 2001; 32: 842-44.

[6] Vyas A, Kim SK, Giacomini N, Boothroyd JC, Sapolsky RM. Behavioral changes induced by Toxoplasma infection of rodents are highly specific to aversion of cat odors.Proc Natl Acad Sci U S A. 2007;104 (15):6442-6447.

[7] Buxton D, Thomson K, Maley S, Wright S, Bos HJ. Vaccination of sheep with a live incomplete strain (S48) of Toxoplasma gondii and their immunity to challenge when pregnant. Vet. Rec. 1991; 129: 89-93.

[8] Bourguin I, Chardès T, Bout D. Oral immunization with Toxoplasma gondii antigens in association with cholera toxin induces enhanced protective and cell-mediated immunity in C57BL/ 6 mice. Infect. Immun. 1993; 61: 2082-2088.

[9] Gazzinelli RT, Wysocka M, Hayashi S, Denkers EY, Hieny S, Caspar P et al. Parasiteinduced IL-12 stimulates early IFN- $\gamma$ synthesis and resistance during acute infection with Toxoplasma gondii. J. Immunol. 1994; 153: 2533-43.

[10] Casciotti L, Ely KH, Williams ME, Khan IA. CD8+-T-cell immunity against Toxoplasma gondii can be induced but not maintained in mice lacking conventional CD4+ T cells. Infect. Immun. 2002; 70: 434-43.

[11] Parker S.J., Roberts C.W. and Alexander J. CD8 ${ }^{+}$T cells are the major lymphocyte subpopulation involved in the protective immune response to Toxoplasma gondii in mice. Clinical and Exp. Immunol, 1991; 84: 207-212.

[12] Suzuki Y. and Remington J.S. Dual regulation of resistance against Toxoplasma gondii infection by Lyt-2+ and Lyt-1+, L3T4+ ${ }^{+}$cells in mice. J. Immunol. 1988; 140: 39433946.

[13] Denkers E.Y., Gazzinelli R.T., Martin D. and Sher A. Emergence of NK1.1+ cells as effectors of IFN-gamma dependent immunity to Toxoplasma gondii in MHC class Ideficient mice. J. Exp. Med., 1993; 178: 1465-1472.

[14] Scharton-Kersten, T.A. Wynn, E.Y. Denkers, S. Bala, E. Grunvald, S. Hieny, R.T. Gazzinelli and Sher A.. In the absence of endogenous IFN-gamma, mice develop unimpaired IL-12 responses to Toxoplasma gondii while failing to control acute infection. J. Immunol. 1096; 157 : 4045-4054 
[15] Suzuki Y., Conley F.K. and Remington J.S. Importance of endogenous IFN-gamma for prevention of toxoplasmic encephalitis in mice. J. Immunol. 1989, 143: 2045-2050.

[16] Suzuki Y., Orellana M.A., Schreiber R.D. and Remington J.S. Interferon-gamma: the major mediator of resistance against Toxoplasma gondii. Science, 1988, $240: 516-518$.

[17] Gazzinelli R.T., Hakim F.T., Hieny S., Shearer G.M. and Sher A. Synergistic role of $\mathrm{CD}^{+}$and $\mathrm{CD}^{+} \mathrm{T}$ lymphocytes in IFN-gamma production and protective immunity induced by an attenuated Toxoplasma gondii vaccine. J. Immunol. 1991, 146 : 286-292.

[18] Shirahata T., Yamashita T., Ohta C., Goto H. and Nakane A. CD8 ${ }^{+}$T lymphocytes are the major cell population involved in the early gamma interferon response and resistance to acute primary Toxoplasma gondii infection in mice. Microb and Immunol, 1994. 38 : 789-796.

[19] Denkers E.Y., Gazzinelli R.T., Hieny S., Caspar P. and Sher A., Bone marrow macrophages process exogenous Toxoplasma gondii polypeptides for recognition by parasite-specific cytolytic T lymphocytes. J. Immunol. 1993. 150 : 517-526.

[20] Hakim F.T., Gazzinelli R.T., Denkers E., Hieny S., Shearer G.M. and Sher A., CD8+ T cells from mice vaccinated against Toxoplasma gondii are cytotoxic for parasiteinfected or antigen-pulsed host cells. J. Immunol. 1991. 147 : 2310-2316.

[21] Subauste C.S., Koniaris A.H. and Remington J.S. Murine CD8+ cytotoxic T lymphocytes lyse Toxoplasma gondii-infected cells. J. Immunol. 1991 147: 3955-3959.

[22] Jordan K.A., Wilson E.H., Tait E.D., Fox B.A., Roos D.S., Bzik D.J., Dzierszinski F. and Hunter C.A. Kinetics and phenotype of vaccine-induced $\mathrm{CD}^{+} \mathrm{T}$-cell responses to Toxoplasma gondii. Infect Immun. 2009. 77: 3894-3901.

[23] Bliss S.K., Zhang Y. and Denkers E.Y. Murine neutrophil stimulation by Toxoplasma gondii antigen drives high level production of IFN-gamma-independent IL-12. J. Immunol. 1999. 163 : 2081-2088.

[24] Robben P.M., Mordue D.G., Truscott S.M., Takeda K., Akira S. and Sibley L.D. Production of IL-12 by macrophages infected with Toxoplasma gondii depends on the parasite genotype. J. Immunol. 2004. 172 : 3686-3694.

[25] Pepper M., Dzierszinski F., E. Wilson, E. Tait, Q. Fang, F. Yarovinsky, T.M. Laufer, D. Roos and C.A. Hunter, Plasmacytoid dendritic cells are activated by Toxoplasma gondii to present antigen and produce cytokines. J. Immunol., 2008. 180 : 6229-6236.

[26] Liu C.H., Fan Y.T., Dias A., Esper L., Corn R.A., Bafica A., Machado F.S. and Aliberti J. Cutting edge: Dendritic cells are essential for in vivo IL-12 production and development of resistance against Toxoplasma gondii infection in mice. J. Immunol., 2006. $177: 31-35$.

[27] Reis e Sousa C., Hieny S., Scharton-Kersten T., Jankovic D., Charest H., Germain R.N. and Sher A. In vivo microbial stimulation induces rapid CD40 ligand-independent production of interleukin 12 by dendritic cells and their redistribution to $\mathrm{T}$ cell areas. J. Exp. Med., 1997. 186 : 1819-1829.

[28] Mashayekhi M, Sandau MM, Dunay IR, Frickel EM, Khan A, Goldszmid RS, Sher A, Ploegh HL, Murphy TL, Sibley LD, Murphy KM. CD8a(+) dendritic cells are the critical source of interleukin-12 that controls acute infection by Toxoplasma gondii tachyzoites. Immunity. 2011. 26;35(2):249-59.

[29] Pifer R. and Yarovinsky F. Innate responses to Toxoplasma gondii in mice and humans. Trends Parasitol. 2011. 27 : 388-393. 
[30] Zhao Y.O., Khaminets A, Hunn JP, Howard JC. Disruption of the Toxoplasma gondii parasitophorous vacuole by IFNgamma-inducible immunity-related GTPases (IRG proteins) triggers necrotic cell death. PLoS Pathog., 2009.5 (2):e1000288.

[31] Zhao Y, Ferguson DJ, Wilson DC, Howard JC, Sibley LD, Yap GS. Virulent Toxoplasma gondii evade immunity-related GTPase-mediated parasite vacuole disruption within primed macrophages. J. Immunol., 2009. 182 : 3775-3781

[32] Scharton-Kersten TM, Yap G, Magram J, Sher A. Inducible nitric oxide is essential for host control of persistent but not acute infection with the intracellular pathogen Toxoplasma gondii. J. Exp. Med., 1997. 185 : 1261-1273.

[33] Pfefferkorn E.R. Interferon gamma blocks the growth of Toxoplasma gondii in human fibroblasts by inducing the host cells to degrade tryptophan. Proc. Natl. Acad. Sci. U.S.A. 1984. 81 : 908-912.

[34] Andrade RM, Wessendarp M, Gubbels MJ, Striepen B, Subauste CS. CD40 induces macrophage anti-Toxoplasma gondii activity by triggering autophagy-dependent fusion of pathogen-containing vacuoles and lysosomes. J. Clin. Invest., 2006. 116 2366-2377.

[35] Ling YM, Shaw MH, Ayala C, Coppens I, Taylor GA, Ferguson DJ, Yap GS. Vacuolar and plasma membrane stripping and autophagic elimination of Toxoplasma gondii in primed effector macrophages. J. Exp. Med., 2006. 203: 2063-2071.

[36] Dimier-Poisson I, Aline F, Mévélec MN, Beauvillain C, Buzoni-Gatel D, Bout D. Protective mucosal Th2 immune response against Toxoplasma gondii by murine mesenteric lymph node dendritic cells. Infect. Immun. 2003; 71: 5254-65.

[37] Ruiz S, Beauvillain C, Mévélec MN, Roingeard P, Breton P, Bout D et al. A novel CD4CD8 $\alpha+C D 205+C D 11 b-$ murine spleen dendritic cell line: establishment, characterization and functional analysis in a model of vaccination to toxoplasmosis. Cell. Microbiol. 2005; 7: 1659-71.

[38] Beauvillain C, Ruiz S, Guiton R, Bout D, Dimier-Poisson I. A vaccine based on exosomes secreted by a dendritic cell line confers protection against $T$. gondii infection in syngeneic and allogeneic mice. Microbes Infect. 2007;9 (14-15):1614-22.

[39] Johnson LL, Sayles PC. Deficient humoral responses underlie susceptibility to Toxoplasma gondii in CD4-deficient mice. Infect. Immun. 2002 ; 70: 185-91.

[40] Gubbels MJ, Striepen B, Shastri N, Turkoz M, Robey EA. Class I major histocompatibility complex presentation of antigens that escape from the parasitophorous vacuole of Toxoplasma gondii. Infect. Immun. 2005 ; 73: 703-11.

[41] Gazzinelli RT, Hakim FT, Hieny S, Shearer GM, Sher A. Synergistic role of CD4+ and CD8+ T lymphocytes in IFN- $\gamma$ production and protective immunity induced by an attenuated Toxoplasma gondii vaccine. J. Immunol. 1991; 146: 286-92.

[42] Martin D, Tarleton R. Generation, specificity, and function of CD8+ T cells in Trypanosoma cruzi infection. Immunol. Rev. 2004; 201: 304-17.

[43] Smith TR, Kumar V. Revival of CD8+ T reg-mediated suppression. Trends Immunol. 2008; 29: 337-42.

[44] Denkers EY, Gazzinelli RT, Martin D, Sher A. Emergence of NK1.1+ cells as effectors of IFN- $\gamma$ dependent immunity to Toxoplasma gondii in MHC class I-deficient mice. J. Exp. Med. 1993; 178: 1465-72. 
[45] Askew D, Harding CV. Antigen processing and CD24 expression determine antigen presentation by splenic CD4+ and CD8+ dendritic cells. Immunology. 2008; 123: 447-55.

[46] Blanchard N, Gonzalez F, Schaeffer M, Joncker NT, Cheng T, Shastri AJ et al. Immunodominant, protective response to the parasite Toxoplasma gondii requires antigen processing in the endoplasmic reticulum. 2008; 9: 937-44. 


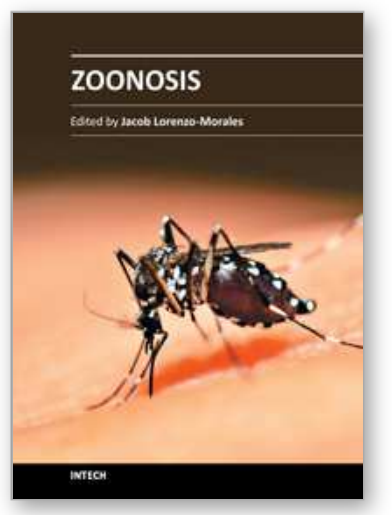

\section{Zoonosis}

Edited by Dr. Jacob Lorenzo-Morales

ISBN 978-953-51-0479-7

Hard cover, 436 pages

Publisher InTech

Published online 04, April, 2012

Published in print edition April, 2012

Zoonotic diseases are mainly caused by bacterial, viral or parasitic agents although "unconventional agents" such as prions could also be involved in causing zoonotic diseases. Many of the zoonotic diseases are a public health concern but also affect the production of food of animal origin thus they could cause problems in international trade of animal-origin goods. A major factor contributing to the emergence of new zoonotic pathogens in human populations is increased contact between humans and animals. This book provides an insight on zoonosis and both authors and the editor hope that the work compiled in it would help to raise awareness and interest in this field. It should also help researchers, clinicians and other readers in their research and clinical usage.

\section{How to reference}

In order to correctly reference this scholarly work, feel free to copy and paste the following:

Isabelle Dimier-Poisson (2012). Major Role for CD8+T Cells in the Protection Against Toxoplasma gondii Following Dendritic Cell Vaccination, Zoonosis, Dr. Jacob Lorenzo-Morales (Ed.), ISBN: 978-953-51-0479-7, InTech, Available from: http://www.intechopen.com/books/zoonosis/major-role-for-cd8-t-cells-in-the-protectionagainst-toxoplasma-gondii-following-dendritic-cell-vacc

\section{INTECH}

open science | open minds

\section{InTech Europe}

University Campus STeP Ri

Slavka Krautzeka 83/A

51000 Rijeka, Croatia

Phone: +385 (51) 770447

Fax: +385 (51) 686166

www.intechopen.com

\section{InTech China}

Unit 405, Office Block, Hotel Equatorial Shanghai

No.65, Yan An Road (West), Shanghai, 200040, China

中国上海市延安西路65号上海国际贵都大饭店办公楼405单元

Phone: +86-21-62489820

Fax: $+86-21-62489821$ 
(C) 2012 The Author(s). Licensee IntechOpen. This is an open access article distributed under the terms of the Creative Commons Attribution 3.0 License, which permits unrestricted use, distribution, and reproduction in any medium, provided the original work is properly cited. 